\section{On the earliest printed portolano (Venice, 1490)}

\section{Andrea Bocchi}

Università degli Studi di Udine, Italy
The International Journal of Maritime History 2020, Vol. 32(3) 729-735

(C) The Author(s) 2020

Article reuse guidelines: sagepub.com/journals-permissions DOI: | 0.1 | 77/084387|420956489

journals.sagepub.com/home/ijh

@SAGE

\begin{abstract}
In November 1490, Bernardino Rizo da Novara issued the earliest printed anonymous portolano. Several months later, a print privilege was issued at the request of Andrea Badoer, a merchant. With the support of a newly published database of Venetian privileges, it is contended that Badoer sponsored the print and possibly provided the text of the portolano.
\end{abstract}

\title{
Keywords
}

early print, medieval navigation, portolans, Renaissance Venice

Venetian privilegi are not a neglected source for the history of geography. As an example, Christopher Witcombe mentions the case of a well-known miniaturist and engraver, Benedetto Bordon, who requested in 1494 a privilege for the whole work (text and prints) of Lucian, a print The Triumph of Caesar in 1504, and a map of Italy and a mappamondo (now lost) in $1509 .{ }^{1}$ A Venetian book privilege was not a permission to print; rather, it was a temporary protection in the territory of the Republic, both in the mainland and in the Venetian islands of the Adriatic and Aegean Sea, that was designed to ensure a that no competitor could publish and sell the same work and thereby make inroads into the publisher's profits for a certain number of years. The privilege system was therefore adopted to protect the economic investment of the publisher and not the rights of the

1. Christopher L. C. E. Witcombe, Copyright in the Renaissance: Prints and the Privilegio in Sixteenth-century Venice and Rome (Leiden-Boston, 2004), 91-6; see Lilian Armstrong, 'Benedetto Bordon, Miniators, and Cartography in Early Sixteenth-Century Venice', Imago Mundi, 48 (1996), 65-92.

\section{Corresponding author:}

Andrea Bocchi, Università di Udine, via Petracco 8, 33100 Udine, Italy.

Email: andrea.bocchi@uniud.it 
author. ${ }^{2}$ During the early modern period, privileges were granted in Venice by the Senate and other offices at the request of an author or printer, so that the relevant documentation is now preserved in the State Archives of Venice. The whole documentation of privilegi has been comprehensively researched by Erika Squassina and made accessible through the database 'Early Modern Book Privileges in Venice', a brilliant example of a friendly and exhaustive work in digital philology. ${ }^{3}$

No scholar seems to have considered the printing privilege granted to the nobleman Andrea di Giovanni Badoer for a portolano in $1491 .^{4}$ Andrea, born in about 1447, was a very experienced merchant with an active interest in maritime trade, who, by the early 1490s, had lived in England for several years and presumably visited at least the most important ports of call in the Eastern Mediterranean. Until the first decade of the sixteenth century, Andrea refused to serve in the Venetian administration; only later, at the age of 62, did he engage in Venetian diplomacy by taking up the important role of negotiating the support of England in the War of the Ligue of Cambrai (1509). Because of his knowledge of England, language skills and diplomatic talent, he subsequently served as Venetian ambassador in London in the complicated years down to 1515. Upon his return to Venice, Andrea was celebrated as one of the most capable diplomats in the Republic. ${ }^{5}$

On 26 April 1491, the Venetian Senate discussed Andrea Badoer's request for a privilegio. The object of Andrea's request was to print a new book comprising a description of every coast, cliff, port, island, shallow, mooring and tidal flow in quaecumque mundi parte:

Since ser Andrea Badoer of the late John wants to print a new and necessary work, for which it will be easy for any sailor to know all the coasts of the world, the rocks, the ports, the islands, the shallows, the anchorages and tidal currents in every part of the world - and this work will be very useful and very safe for all sailors - then he pleaded that by completing and printing such a useful and necessary work, no one can have this work printed for ten years continuously in our city of Venice and in all our lands and cities. Because of such a profitable and praiseworthy offer, not at all to neglect, our judgment should allow Andrea Badoer to print and have printed this work in our city and in all our territories and that no one can print or have printed the

2. For an updated and comprehensive overview of the Venetian privilege system, see Angela Nuovo, The Book Trade in the Italian Renaissance (Leiden-Boston, 2013), 195-257. I am deeply indebted to Angela Nuovo for amicable and fruitful discussion of the subject of this paper.

3. This resource has been created in the context of the ERC-funded 'EMoBookTrade' Project (P.I. Angela Nuovo, University of Milan). The database of Venetian privileges comprises about 2,600 concessions from the 1469-1603 period, with the privilege granted to Badoer catalogued as ID 751. I am profoundly grateful to Erika, who during our collaboration as members of the EMoBookTrade research team pointed out this privilege to me. See: http:// emobooktrade.unimi.it

4. An isolated reference can be found in a note in Martin Lowry, The World of Aldus Manutius: Business and Scholarship in Renaissance Venice (Ithaca, 1979), 9, 41, 47 (with erroneous reference to 'navigational charts'); he points out that Andrea was one of the very few Venetian noblemen who requested a privilegio.

5. Angelo Ventura, 'Badoer, Andrea', in Dizionario biografico degli Italiani, vol. 5 (Rome, 1963), 96-8. 
aforementioned work for the next ten years in this city or in other cities and our lands both on land and at sea, under penalty of losing all printed books. Therefore it shall be lawful for our nobleman or his envoys to confiscate these books with their forms and burn them or dispose of them as he wants. ${ }^{6}$

In his request, Andrea did not mention the only printed predecessor, the anonymous Libro chiamado portolano, published by Bernardino Rizo da Novara on 6 November 1490, and lately attributed to the well-known explorer Alvise da Mosto. ${ }^{7}$ However the request clearly cites (in Latin, the language of the administration) the very first page of Rizo's Portolano:

This is a necessary work (una opera necessaria) for all sailors who go to the different parts of the world, by which everyone can learn to identify the coasts, the seabeds, the inlets, the ports, the currents (corsi d'acque) and the tides, starting from the city of Cadiz in Spain to arrive in

6. Venice, State Archives, Senato Terra, Reg. 11, fol. 62r: 'MCCCCLXXXXI, die xxvi aprilis. Cum vir nobilis ser Andreas Baduario, quondam ser Joannis, cupiat imprimi facere Opus quoddam novum et necesarium, per quod facillimum erit quibuscumque navigantibus cognoscere posse omnia littora terrena, scopulos, portus, insulas, banchas, sorzatores et cursus aquarum in quacumque mundi parte; quod quidem opus utilissimum et tutissimum futurum est omnibus navigantibus, ideo supplicavit, ut conficiente, et imprimente eo, tam utili et necessario opere, nemo possit id opus imprimi facere per annos decem continuos in hac urbe nostra et in omnibus terris et locis nostris. Cum igitur non sit ullo modo, tam laudabilis, et proficua oblatio aspernenda, ideo vadit pars quod idem ser Andreas Baduario imprimere et imprimi facere possit in hac urbe et in quibuscumque terris et locis nostris opus predictum, nec possit aliquis sitque velit predictum opus imprimere vel imprimi facere per annos decem proximos venturos in hac urbe vel in aliis terris et locis nostris tam a parte terre quam a parte maris, sub pena ammittendi libros omnes impressos. Et liceat ipsi nobili nostro, vel nuntiis suis, omnes huiusmodi libros impressos cum forma predicte partis, accipere et illos comburere, vel aliter disponere sicuti ei placuerit. De parte 152. De non 15. Non sinc. 5. Consiliarii: ser Marcus de Garzonis, ser Constantinus de Priolis, ser Hieronimus Vendraminus, ser Iacobus de Musto, ser Alvisius Bragadinus.'

7. ISTC ip00945000, IGI 8034. The attribution is found in a note by Francesco Sansovino, Venetia, citta nobilissima et singolare descritta in XIIII libri (Venice, 1581), 250: '[Alvise] wrote a book called portolan but without his name' (where Sansovino does not mention a printed book). This has been discussed by Placido Zurla, Di Marco Polo e degli altri viaggiatori veneziani più illustri (Venice, 1819), 106-7; Giuseppe Melzi, Dizionario di opere anonime e pseudonime di scrittori italiani. Supplemented by Giambattista Passano (Ancona, 1887), 362; and Andrea da Mosto, 'Il portolano attribuito ad Alvise da Ca' da Mosto', Bollettino della Società geografica italiana, 6 (1883), 547. The reference is absent in the 1556 and 1561 editions of Sansovino's work; it is likely to be conveyed by the friendly connection with the family of Giovan Battista Ramusio (1485-1557), who printed the account of Alvise's explorations in the first volume of his Navigationi e viaggi (Venice, 1550). It must also be observed that in 1544 a different portolano was printed (Nuovo portolano; see Bartolommeo Gamba, Serie degli scritti impressi in dialetto Veneziano (Venice, 1832), 49; and Mosto, 'Il portolano', 549) without the first section devoted to the Atlantic coast. I would like to thank Maria Cristina Panzera (Univ. Bordeaux Montaigne) for discussing with me issues relating to Sansovino's reference. 
the port of Sluis through the channels between the island of England and the mainland along from the shallows (banche) of Flanders to the island of Ireland . . .

Among the officers selected to examine the request was Iacopo da Mosto; therefore, it is unlikely that these expert merchants would have missed the reference to Rizo's Portolano. However, Andrea did not use the term portolano, which initially denoted a collection of nautical charts, ${ }^{9}$ and was also used to describe printed books by the sixteenth century. ${ }^{10}$ It is remarkable that the same elements of geographical description are expressed in vernacular words (with Latin inflexion) both in the request, and in the printed portolano: banchas, sorzatores et cursus aquarum. ${ }^{11}$

The request was approved by a large majority of senators (152 voted in favour, 15 dissented and five abstained); however, no new portolano would be printed in Venice until 1528, while no work authored or edited by Andrea Badoer is known. We can conclude that the new portolano was not completed. My hypothesis is that this privilegio was requested for the already published Portolano of Rizo in order to protect that pioneering work against unfair competition. It was not uncommon - according to the data available in the 'Early Modern Book Privileges in Venice' database - to request a privilege for a book that had already been printed: for example, Anton Kolb, a German merchant, obtained in October 1500 a privilege for Jacobo de Barbari's famous map of Venice 'because he (in order to celebrate that most excellent city) portrayed and printed

8. Portolano by Rizo, c. a2: 'Questa e una opera necessaria a tutti li naviganti chi vano in diverse parte del mondo, per la qual tutti se amaistrano a cognoscere starie, fundi, colfi, vale, porti, corsi dacque e maree cominciando da la cità de Cadex in Spagna dretamente fina nel porto de le Schiuse passando per i canali fra la ixola de Ingelterra e la terraferma scorendo le banche de fiandra fino a la ixola de Irlanda.'

9. Giorgio Varanini, 'Un inventario veronese del sec. XV', in Paola Benincà, ed., Studi in onore di Giovan Battista Pellegrini (Pisa, 1983), 469: 'a book called portollan costs 6 ducats' (1 libro se chiama portollan ducati vi); the high price suggests that the book included maps. See Manlio Cortelazzo and Paolo Zolli, Dizionario etimologico della lingua italiana $\left(2^{\text {nd }}\right.$ edn., Bologna, 1999), s.v.

10. For example, the Portolano delli Lochi maritimi (with seven wood-cut maps).

11. Note the feminine banca 'bassofondo': the word is widespread in Venetian and later in Italian as a masculine: see banco in Elda Morlicchio, Lessico etimologico italiano. Germanismi [Wiesbaden, 2015-], I, col. 417; Cortelazzo and Zolli, Dizionario, s.v.; Dizionario di marina medievale e modern (Rome, 1937), s.v.; Giuseppe Boerio, Dizionario del dialetto veneziano (Venice, 1856), s.v. banco. But it is very rarely written as a feminine expression in the portolano and in privilegio: see Pamela O. Long, David McGee and Alan M. Stahl, eds., The Book of Michael of Rhodes: A Fifteenth-Century Maritime Manuscript (Cambridge, MA, 2009), always bancho; and Konrad Kretschmer, Die italianischen Portolane des Mittelalters: Ein Beitrage zur Geschichte der Kartographie und Nautik (Berlin, 1909), 353, 358, banco and banca in the Portolano of Rizo only. Sorzadore ('mooring place') is a usual term both in sixteenth-century Venice (Manlio Cortelazzo, Dizionario veneziano della lingua e della cultura popolare nel XVI secolo [Padua, 2007], s.v. sorzador), and in earlier portolani: see Alessandra Debanne, Lo Compasso de navegare: Edizione del codice Hamilton 396 con commento linguistico e glossario [Bruxelles, 2011], 282. For cursus aquarum and corsi dacque '(tidal) flow', see Henry et Renée and Lucille Bremner, Glossario degli antichi portolani italiani (Florence, 1968), 44. 
the city of Venice, and that work [was] completed after three years'. ${ }^{12}$ Sometimes the request did not mention that the printing had already taken place; nevertheless, the date of the colophon shows that the privilege was granted after the publication, perhaps due to a delay in the bureaucratic process; for example, the Expositio, by Dino del Garbo on Avicenna's Cyrugia, was published by Bonello Locatello on 24 December 1496, whereas the privilege was granted on 19 April $1497 .{ }^{13}$ The same is likely to have happened with Andrea Badoer.

Accordingly, Andrea was probably involved in the printing of the earliest Venetian Portolano, although we do not know in what way. He might have envisaged the chance to gain some money from financing its production, or he might have just provided the text, even if his name does not occur in the book. Or, he could have written some parts of the Portolano, possibly reworking a manuscript portolano on the basis of his personal experience and documentation. ${ }^{14}$

As for the maritime experience illustrated, the Portolano by Rizo could in fact be written by Andrea Badoer as well as (or even better than) Alvise da Mosto, given the content of the text preceding the colophon of Portolano, fol. [79v]: 'written by a Venetian nobleman, who visited all the countries here depicted' (portolano composto per vno zentilomo veniciano lo qual a veduto tute queste parte anti scrite). As far as we know, Alvise, who was born in approximately 1429 and died in 1483, sailed the Eastern Mediterranean between 1442 and 1448 in Venetian galleys, travelled as a merchant in Crete and the Barbary Coast and embarked as a balestriere on a Venetian galley to Flanders. On his second voyage to Bruges, aged 25, he left the Venetian commercial fleet in Cabo Sao Vicente and entered into the service of the Portugal Crown, in which he completed two important voyages of discovery to Gambia, on the western coast of Africa, and the Cape Verde Islands (1455-1456) before returning to Venice in February 1463 or $1464 .{ }^{15}$ It must be pointed out that Rizo's Portolano does not mention any

12. Venice, State Archives, Collegio Notatorio, vol. 15, fol. 28r (ID 522 in the Early Modern Book Privileges in Venice database): 'cum sit che lui principalmente ad fama de questa Ex.sa cità de Venetia, habia facto justa et propriamente retrare et stampare, la qual opera hora, de poy lo tempo di tre anni, fornita'. The request in the privilege was for three years, but the officers granted it for four years.

13. Venice, State Archives, Collegio Notatorio, vol. 14, fol. 157r, concerning Dinus de Garbo, Expositio super tertia, quarta, et parte quintae fen IV, libri Avicennae, ISTC id00195000 (ID 179 of Early Modern Book Privileges in Venice database). That practice seems to be more common in case of request of several privileges at once (as Locatello did; see ID 177 and 180, and ID 417, 420 for other examples) and later in the sixteenth century.

14. Such a collaborative process has been detected in several maritime or commercial texts, both producing manuscripts (e.g., Piero de Versi signed the portolano by Michael of Rhodes: The Book of Michael of Rhodes, vol. III, xvi) and prints (the Libro della mercatura written by Benedetto Cotrugli in 1458 was copied and reworked several times by Venetian and Florentine hands and lately revised and printed by Francesco Patrizi in 1573: see Benedetto Cotrugli, Libro de l'arte de la mercatura (Venice, 2016): it is a common feature of many fifteenth-century books in the professional field.

15. The African explorations by Alvise were well known in Venice, and recorded by the cartographer Grazioso Benincasa after Alvise's return in the 1460s; in the same years, he wrote the 
African city west of Alexandria, and does not refer to Morocco or the Canary Islands; moreover, if the Portolano was produced by Alvise, we must assume that, as a balestriere still in his twenties, he would have been able to describe in a single voyage the whole Atlantic coast, as well as depicting the challenging tidal flows of Flanders and Brittany, ${ }^{16}$ the whole periplus of Ireland, ${ }^{17}$ and the Bay of Biscay from one sea port to another. ${ }^{18}$ More realistically, what we can conclude is that our portolano was composed over a long time on the basis of a rigorous appraisal of various sources. Although it may have been put together with the help of Alvise's records, it makes no reference to his remarkable explorations. On the other hand, Andrea Badoer, according to his privilege, probably played a role in the portolano production, contributing at least to the Atlantic section with his unique experience, which gained him, although aged and unfamiliar with diplomacy, the post of ambassador in England.

\section{Acknowledgements}

The research underpinning this publication was funded by the European Research Council (ERC) through the European Union's Horizon 2020 research and innovation programme. It forms part of the ERC project 'EMoBookTrade' (grant agreement 694476).

\section{Author biography}

Andrea Bocchi graduated in the History of Italian Language at University of Pisa in 1989, studied at Scuola Normale Superiore and Universität des Saarlandes, and was awarded doctorates by SNS (2003) and Pisa University (2010). He teaches Digital Philology at the University of Udine, and has published commercial, mathematical, literary and administrative documents from medieval Marche, Umbria, Tuscany and Veneto. His recent books concern the European history of the word 'demagogue' (L'eterno demagogo [Turin, 2011]), a Trecento latin-italian dictionary (Il glossario di

journal of his African Navigazioni, which was edited by Fracanzio da Montalboddo and later collected by Ramusio. See Fracanzio da Montalboddo, Paesi nouamente retrouati et nouo mondo (Vicentia, 1507); Ugo Tucci, 'Da Mosto, Alvise', in Dizionario biografico degli italiani, vol. 32 (Rome, 1986); Camillo Tonini and Piero Lucchi, eds., Navigare e descrivere: Isolari e portolani del Museo Correr di Venezia XV-XVIII secolo (Venice, 2001), 91-5, note 16.

16. In this section, the Portolano (foll. a3r-a4r) mentions names of places not reported by any other portolans and maps, like La Guardia near Ostende and Fossa de Chaio near Dieppe (see Kretschmer, Die italianischen Portolane, 561), and offers in a dedicated section some bathygraphic data, that were customarily employed in northern European navigation techniques but less common in Mediterranean practice.

17. Foll. [a6rv]. The Irish place names (here with the respective distances expressed in nautical miles) are usually omitted in Italian portolani, while they are included in the best maritime charts.

18. It must be remembered that the itinerary of the state galleys was strictly predetermined and did not leave any space for unplanned stops: 'The Flanders route routinely included stops at Palermo and Messina in Sicily, at Mallorca, at Malaga [. . . ] then through the Straits of Gibraltar to Cádiz and Lisbon' (Stahl in the Book of Michael of Rhodes, vol. II, 54); Alvise's unscheduled stop at Cabo Sao Vicente was actually due to bad weather. For the journal of a fourteenth-century Venetian convoy to the West, see Giovanni Foscari, Viaggi di Fiandra 1463-1464 e 1467-1468 (Venice, 2012). 
Cristiano da Camerino [Padua, 2015]), the plays of a Venetian dramatist (Francesco Griselini, Teatro [Pisa, 2015]), a Pisan translation of Ricoldo da Montecroce's itinerary in Middle East (2017), and he is currently working on a Trecento Latin poem about factions in an Italian commune, the earliest Venetian mariner's book, and the fifteenth-century portolano of Grazioso Benincasa. 